\title{
Understanding the stakeholders' role in a business failure situation: An empirical boosting approach
}

\author{
Alba María Priego-de-la-Cruz ${ }^{a}$, Esteban Alfaro-Cortés ${ }^{b}$, Montserrat Manzaneque-Lizano $^{c}$ \\ a) Financial Economics, Accounting and Operations Management departament, Faculty of Business Sciences and Tourism, Huelva University. Spain \\ b) Faculty of Economics and Business, Quantitative Methods and Socio-economic Development Group, Institute for Regional Development (IDR), University of Castilla-La \\ Mancha. Albacete, Spain \\ c) Department of Business Administration, External and Internal Information Systems of Organizations: Corporate and Management Information Group (GISEIO), \\ Castilla-La Mancha University. Cuenca, Spain
}

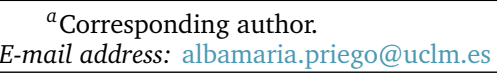

\section{A R T I C LE IN F O \\ A B S T R A C T}

\section{Article history:}

Received 21 March 2019

Accepted 31 May 2019

Available online 1 January 2020

\section{JEL classification:}

G33

M14
C38

Keywords:

Stakeholder

Stakeholder

Business failure

Boosting method
Relative importance
We investigate the stakeholders' role in a business failure situation. In particular, we analyse which primary stakeholders have an impact on the business failure, and how. This work also proposes an order of prioritization of primary stakeholders with the purpose of showing business managers useful information which guides their decisions to reduce the emergence of conflicts of interest that may affect the sustainability of firms long-term in financial crisis situations. We have taken a sample of 2,352 Spanish SMEs, 1,176 non-failed firms matched with 1,176 failed firms, from which economic and financial data are been extracted from their financial reporting. In this vein, logistic regression and boosting methodologies have been applied. The findings indicate that the primary stakeholders have a statistically significant effect on the likelihood of business failure. Furthermore, the results present a ranking of primary stakeholders related to their impact on the likelihood of business failure in contexts of financial crisis. Thus, our study provides a useful guide to managers seeking to understand the primary stakeholders roles and their relative priority in business failure.

(C)2020 ASEPUC. Published by EDITUM - Universidad de Murcia. This is an open access article under the CC BY-NC-ND license (http://creativecommons.org/licenses/by-nc-nd/4.0/).

El rol de los stakeholders en situaciones de fracaso empresarial: Un enfoque empírico mediante boosting

R E S U M E N

Este estudio investiga el rol de los stakeholders en situaciones de fracaso empresarial. En concreto, analiza qué stakeholders primarios tienen impacto en la probabilidad de fracaso de una empresa y cómo lo ejercen. También propone un orden de priorización de los stakeholders primarios con la finalidad de ofrecer a los gestores empresariales información útil para que, ante situaciones de crisis financiera, orienten sus decisiones a reducir la aparición de conflictos de intereses que pueden afectar a la sostenibilidad de la empresa a largo plazo. De esta forma, se ha tomado una muestra de 2.352 pymes españolas, 1.176 empresas sanas emparejadas con 1.176 empresas fracasadas, de las que se han extraído datos económico-financieros de sus cuentas anuales y a los que se han aplicado las metodologías de regresión logística y boosting. Los resultados obtenidos indican que los stakeholders primarios tienen efecto estadísticamente significativo en la probabilidad de fracaso empresarial. Además, los resultados presentan un ranking de stakeholders primarios en relación con su impacto en la probabilidad de fracaso empresarial ante contextos de crisis financiera. De esta forma, este estudio propone una guía útil para los gestores mostrando los roles de los stakeholders primarios y su orden de prioridad ante una situación de fracaso empresarial.

(C)2020 ASEPUC. Publicado por EDITUM - Universidad de Murcia. Este es un artículo Open Access bajo la licencia CC BY-NC-ND (http://creativecommons.org/licenses/by-nc-nd/4.0/). 


\section{Introduction}

The debate about the role of the stakeholders in the future of the firm has further intensified during the global financial crisis because of the prevailing economic uncertainty and instability around the world, which has affected businesses in countries such as Italy, Spain, the United States (US) and the United Kingdom (UK) (International Monetary Fund (IMF), 2012). The consequences of firm failure are very costly for society (Carter \& Van Auken, 2006; Madrid-Guijarro et al., 2011). In fact, the crisis consequences have been especially severe in Spain where unemployment increased from $8 \%$ to $25 \%$ and the economy underwent negative real GDP growth (IMF, 2012; Villanueva-Villar et al., 2016). This could be due to Spanish business structure is characterized by high percentage of SMEs (small and medium enterprises) (around $99 \%$ in 2018 according to the Nacional Institute of Statistic) with greater rates of failure than large firms $(41.75 \%$ of SMEs were at risk of bankruptcy compared to $39.8 \%$ of other companies in 2013 according to the report of SFAI Spain for $2013^{1}$ ) and very dependent on other stakeholders for obtaining resources (Hessels \& Terjesen, 2010), making firms more vulnerable to their influence. These reasons make the Spanish context very interesting for the analysis of stakeholders' impact on business failure likelihood under unstable macroeconomic situations.

Previous literature has broadly supported the stakeholders' influence on the achievement of traditional firm's goals. Specifically, stakeholder theory provides strong arguments about how firms should implement a business management focusing on a stakeholder approach that considers stakeholders' roles and concerns into their organizational policies and practices because they impact on the firms' outcomes and survival. Additionally, resource dependence theory argues that stakeholders are resource-holders and firms depend on them to obtain sustainable long-term performance and survive on the future (Barney \& Arikan, 2001; Choi \& Wang, 2009). In this line, the widespread literature related to stakeholder management has showed that stakeholders impact positively on the firms' outcome. Choi and Wang (2009) advise, for example, that having good relationships with primary stakeholders help firms with poorly performance to improve their financial and economic situation. Accordingly, stakeholder management perspective has been implemented to analyse some business issues, for instance, how firms generate and distribute added value, how firms obtain performance (Parmar et al., 2010), or how stakeholder, namely, primary stakeholders, influence on the likelihood of bankrupting (James, 2016). Nevertheless, the proper development of works which shed light in how stakeholders' role impact on a firm in financial crisis conditions is still scarce due to most empirical researches focus on stable financial situations (Choi \& Lin, 2009). This study provides insight into how factors link to stakeholder are associated with financial distress in periods of financial crisis.

Particularly, in financial crisis macroeconomic environments, there are studies which highlight that stakeholders' roles may change regarding financial stable situations and important conflicts of interest could appear among stakeholders. In this regard, when firms' ability to create and capture value is low, there are fewer resources to distribute to each stakeholder, and those with greater ability or power would maximize their own interests at the expense of others (Berle \& Means, 1932; Jensen \& Mecking, 1976; Jensen, 1983). Ac-

${ }^{1}$ Taken from http://www.derechos.org/nizkor/espana/doc/pymes1. cordingly, under these circumstances it could be difficult for managers to perform strategic actions that increase the value of different stakeholders simultaneously making them to collaborate in the achievement of the main firm goals, as stakeholder synergy perspective posits (Tantalo \& Priem, 2016). Therefore, stakeholder synergy can be diminished by different stakeholders' roles, arising conflicts of interests under financial crisis scenarios and making difficult to extrapolate the results and conclusions of previous research on stakeholders influence on firm outcomes. For this reason, in order to avoid harmful stakeholders' impact on the firm that may increase the likelihood of business failure, managers might focus on being well informed about stakeholders, namely, about primary stakeholder relationships, which are vital to the firm survival (Clarkson, 1995; Hummels, 1998), and trying to prioritize which of them deserve broad consideration in their business goals or strategies. According to the prioritisation of stakeholders into the business goals, previous literature has showed several rankings of stakeholders that may help firms to categorize them in order to the possession of some attributes such as power, legitimacy or urgency (Mitchell et al., 1997), the higher to lower salience in the SME context (Sen \& Cowley, 2013) and so on. However, the proper development of stakeholders' ranking is not conclusive at all because all of them are set in stable economic and financial situations. As we discussed above, in financial crisis contexts the most significant primary stakeholders for the survival of the firm could change regarding those significant in stable financial situations. This is why we focus our study on that kind of contexts.

Although stakeholder works have made progress in understanding and categorizing how stakeholders' roles may impact on the firms' outcome, there are still few studies analysing how stakeholders might respond in financial crisis (James, 2016). In this vein, this work addresses this gap regarding how stakeholders' roles, through analysing their vital resources that are need by firms' goals, may perform in different economic and financial environments and how firm should rank them in these unstable macroeconomic contexts. In fact, researchers have suggested that stakeholders' roles are important in determining the firm outcome (e.g., McDonald \& Härtel, 2000; Pajunen, 2006; McDonal et al., 2010; Granda \& Trujillo, 2011), but according to Choi and Lin (2009) and James (2016) there are unanswered questions regarding their roles in a financial crisis context and, also, how firms should prioritize them in these unstable contexts (Sen \& Cowley, 2013).

On the basis of this rationale, the purpose of this paper is to analyse the role of different stakeholders, in particular, primary stakeholders in the Spanish SMEs because of their essential resources and importance in a business failure situation and to propose a ranking of them in order to avoid the bankruptcy of the firm in unstable macroeconomic situations. Specifically, we test the following research questions: first, which primary stakeholders have a significant impact contributing to the increase on the likelihood of business failure of a firm, and how?; and second, how should a firm prioritize primary stakeholders according to their impact on the likelihood of business failure?

In order to provide answers to the above research questions, an empirical study has carried out based on logistic regression models and boosting methods and using a sample of 2,352 Spanish SMEs, matched between failed and non-failed, during the early years of the financial crisis, from 2006 to 2010. On the one hand, the results reveal the nature of the primary stakeholders related to the firms and how their comhtml. 
peting roles may affect firms' outcomes, and thus the likelihood of a firm's survival when it undergoes financial crisis conditions. On the other hand, we propose a primary stakeholders priority ranking to avoid bankruptcy when the firm is in an unstable macroeconomic situation.

Moreover, the contributions of this research are based on theoretical and methodological approaches. Regarding the theoretical approaches, we extend the stakeholder literature by studying primary stakeholder impact on the likelihood of business failure in unstable economic and financial situations. In this regard, we answer the call from some works on studying how stakeholders affect in the likelihood to business failure of firms under financial crisis (James, 2016). In fact, this study proposes a ranking of primary stakeholders according to their impact on the likelihood of a business failure situation. Holding true that, in an unstable macroeconomic situation, it is also kept the relative importance of managing some key stakeholders such as employees and customers as others works propose in stable contexts (Preston \& Sapienza, 1990; Berman et al., 1999; Dunham et al., 2006; Sen \& Cowley, 2013). In so doing, we discuss the stakeholders' synergy perspective under a crisis context, pointing out that firms can not consider stakeholders simultaneously in unstable situations since stakeholders' expectations are different and they could act egoistically under the suspect of their wealth expropriation from other stakeholders with greater power over the firm value. Therefore, we address the call of some works (Sen \& Cowley, 2013) which suggest the proposition of a stakeholders' ranking in unstable situations. Finally, this work contributes to the stakeholder and resource dependence theories examining how primary stakeholders' roles, thought analysing their resources that are needed for firm outcome, impact on the likelihood of business failure and how firms should rank them according to their higher to lower salience in unstable macroeconomic situations.

From a methodological point of view, this work extends the use of boosting methodology in the business failure literature (Alfaro et al., 2008a \& b) and is the first to use this method to propose a ranking of stakeholders according to their statistical contribution to the explanation of the likelihood of business failure. In this sense, this methodology provides empirical evidence on the order of priority in which primary stakeholders' roles should be considered (i.e., their relative importance) by firms facing business failure. The methodology provides accurate predictions of business failure and is thus a useful statistical model that can help prevent business failure situations.

The rest of the paper is organized as follows. First, we begin by presenting the literature review in this field of study. Second, we describe our research methodology, which involves the use of logistic regression models and determines the relative importance of our variables by means of a boosting method. Finally, we detail the main conclusions.

\section{Literature review}

Previous studies on the field of business failure have attributed the failure of the firm to different financial and economic internal factors (Altman, 1968; Altman et al., 1977; Ohlson, 1980; Zavgren \& Friedman, 1988; Gilbert et al., 1990; Koh \& Killough, 1990; Platt \& Platt, 1990; Tascón \& Castaño, 2012; Manzaneque et al., 2016), human capital quality (Schutjens \& Wever, 2000; Lee \& Tsang, 2001), environment conditions (Everett \& Watson, 1998; Brixy \& Grotz, 2007) or poor management decisions (Carter \& Van Auken, 2006), among other things. However, stakeholders influence on business failure it has not received much attention in the literature (James, 2016).

In business management, stakeholders approach has been addressed from different theoretical perspectives. From the point of view of the stakeholder theory, firm can be seen as a set of relationships between its stakeholders and without them it would cease to exist (Freeman, 1984). This theory argues that firms have the obligation and the responsibility to balance the rights and interests of all stakeholders who have a claim on the firm (Hummels, 1998), because stakeholders' roles can affect firm survival (Harrison \& Freeman, 1999; Jones \& Wicks, 1999; Larrinaga-Gonzalez, 2007; Agle et al., 2008; Parmar et al., 2010).

According to the above arguments, previous literature has analysed how stakeholder's role impact on the achievement of traditional firm goals (Donaldson \& Preston, 1995), such as, performance, added value and so on, therefore, they may influence on the firm's survival. Drawing on the widespread theoretical works, Fassin (2012) argues, from a strategic point of view, that firms should focus their business management on the impact that their actions may have on the stakeholders, but at the same time ensuring that the firms' goals are met. Namely, firms have a moral duty to take into account the legitimate needs, earned rights and expectations of all primary stakeholders and to provide fair treatment and proper distribution of the business wealth (Hummels, 1998; Fassin, 2012). Additionally, Fassin et al. (2017) highlight the importance of having relationships among stakeholders in the firms' value-creation process. Similarly, Minoja (2012) argues that the generation and distribution of value added of the firm depends on its stakeholders' collaboration and support. In this sense, as expressed by Donaldson and Preston (1995), stakeholder theory can help as a guide to managers' actions, for instance, showing how value is created, destroyed and redistributed through stakeholder relationships (Griffin, 2017), that is, firms have to consider and manage all the stakeholders who have an influence on the continued survival of the firm (Hummels, 1998). Summarizing, stakeholder management "refers to the development and implementation of organizational policies and practices that take into account the goals and concerns of all relevant stakeholders" (Post et al., 2002: 2) because they may influence on the traditional firm's goals, thus, on the firm's survival.

Also, stakeholder influence on the firm has been approach from the resource dependency theory which assumes that firms are not self-sufficient, since they do not control all the necessary resources to carry out their activities (Pfeffer \& Salancik, 1978). For this reason, firms are vulnerable to their organizational environment, generating relationships between all stakeholders (Grant, 1996). As Derry (2012) asserts, stakeholders are resource-holders and firms depend on them for their survival. In this line, it must be recognized the importance of resources for business outcomes (Penrose, 1995) because firms depend on the stakeholders who have the resources and information that they need to carry out their activities. But according to Fassin (2012), the power over resources is unequally distributed among stakeholders. This leads to the logical conclusion that firms' goals should aim to satisfy the needs of the stakeholders who have control and power over critical resources for the firms (Jawahar \& McLaughlin, 2001) in order to assure its survival in the future. The greater the power of certain stakeholders, the greater the likelihood that firms will meet their interests and demands (Frooman, 1999; Kassinis \& Vafeas, 2006). In summary, the firms' strategic management should be based on establishing good relationships with their stakeholders because they 
are regarded as a valuable, unique and non-substitutable resource that contribute to superior firm performance (Barney \& Arikan, 2001; Choi \& Wang, 2009) and thus reduce the likelihood of business failure.

Following the above theoretical arguments, we highlight that there are also several empirical studies which confirm that stakeholder impact on the achievement of firm's outcomes, and thus survival. Following this line, there are research that confirm that encourage good stakeholder relationships lead to improved firms' value and, therefore, to avoid difficult economic and financial situations (Parmar et al., 2010; Tantalo \& Priem, 2016). Additionally, Hillman and Keim (2001) argue that good relationships, namely, with primary stakeholders, impact positively on the improvement of added value. With regard to firms' performance, some works have pointed out that meeting stakeholders' expectations can improve performance (Perrini, 2006; Worthington et al., 2006; Fisher et al., 2009) and can thus help to ensure the firms' long-term survival. Similarly, there is literature that confirms a positive relationship between treating stakeholders properly and firm performance (Kacperczyk, 2009; Freeman et al., 2010; Parmar et al., 2010). In this line, Choi and Wang (2009), integrating the resource dependence and stakeholder theories, find that good relationships with nonfinancial stakeholders, such employees, suppliers, customers and communities, impact on firm's performance. The authors show that good stakeholder relationships help firms to sustain their performance for a longer time, and, more important, to enhance poorly performance firm to improve from difficult situations. In similar way, a more recent study, conducted by James (2016) with a sample which includes all chapter 11 bankruptcy filing publicly traded firms, confirms that primary stakeholders, such as employees, customer, suppliers, creditors and shareholders, influence on firms' likelihood of bankruptcy. In particular, having unfavorable contracts with primary stakeholders increase the likelihood of bankruptcy. For instance, the author shows that having unfavorable contractual arrangement with supplier or creditors affects the firm's performance. In so doing, these harm stakeholder relationships may have irreversible negative effect on the performance of firms with economic and financial difficulties (Hambrick \& D'Aveni, 1988; Platt et al., 2011). And, finally, there is a study which shows evidences of how stakeholders' behaviours impact on the likelihood of business failure through their participations in the generation and distribution in the firm's added value (Priego et al., 2014). These findings support the belief that a stakeholder management perspective helps to prevent a business failure situation.

As stated above, previous literature has highlighted the importance of managing key stakeholders because they impact on firm's outcomes and thus in firm's survival. Nevertheless, the proper development of stakeholder management in business failure situations is still scare due to most empirical works have been focused on stable economic and financial contexts. Therefore, several authors (Choi \& Wang, 2009; James, 2016) have argued the need of stimulating further research related to how firms should manage stakeholders when firms are facing economic and financial difficult situations because they perform a key role in the firm under these situations (Parmar et al., 2010).

Considering the aforementioned arguments, in this research, we focus on determining which stakeholders have an impact on firms' outcomes in financial crisis contexts, and how they do so in order to perform a properly stakeholder management. To this respect, we are especially interested in primary stakeholders' roles, such as shareholders, customers, employees, suppliers, financial creditors and management (Clarkson, 1995), due to the fact that they "are vital to the survival and success of the organization" (Hummels, 1998: 1407). Consequently, we formulate the following hypothesis:

\section{H1: Primary stakeholders impact significantly on the likelihood of business failure.}

As we posit above, it is important to find empirical evidence about which stakeholders impact on firms' outcomes and how, when firms are fighting for survival. In this sense, firms are vulnerable to their organizational environment, generating interdependence relationships between stakeholders (Grant, 1996). In this regard, Tantalo and Priem (2016) develop a new theoretical framework, labelled stakeholder synergy, for value creation where they show that certain strategic actions may increase the value of different types of stakeholder groups simultaneously, namely, for those stakeholders that are essential to firms' survival. Since this situation is likely to lead to gain competitive advantage and a high financial performance. However, under financial crisis situations the conflict of interest between stakeholders arises. In this sense, to perform well managers have to pay attention to a ranking of stakeholders (Sen \& Cowley, 2013) which may influence on firms' value and, thus, survival. Following the above arguments, previous literature has presented some stakeholder rankings. In this sense, we highlight Robert Wood who, in 1947, assigns an order of importance of stakeholders such as customers, employees, community and shareholders (Preston \& Sapienza, 1990). Wood argues that if firms look after the interests and demands of the first three groups of stakeholders, the firm's shareholders would benefit in the long-term (Hummels, 1998). In 1997, Mitchell et al. (1997) perform a theorical stakeholder salience model to understand the stakeholder relative importance focused on their possession of the following attributes: power, legitimacy and urgency. According to Mitchell et al. (1997)' stakeholder salience model, Sen and Cowley (2013) list a ranking of stakeholder relative importance in SME depending on their higher to lower salience, in such a way that owners, employees, customers and suppliers are the most important stakeholders to be considered. In the same way, Dunham et al. (2006) list the stakeholders into two groups: first, cooperation, with stakeholders who affect and are affected by the firm; and, second, collaboration, with stakeholders on whom the firm trusts for support such as employees, suppliers and customers. In this line, Berman et al. (1999) indicate that managers should focus on customer and employees, as key stakeholders, that can improve firms' performance.

Although the above theoretical rankings are trustworthy in a stable economic and financial context, the business environment may change the sequence, as Sen and Cowley (2013) explain. In other words, in financial crisis contexts, firms may disregard some of the stakeholders' interests and demands when setting their goals. That is, businesses, fighting for survival, cannot be expected to take into consideration the ranking of stakeholders that are contemplated under stable economic and financial situations. Furthermore, in a complex environment, stakeholder synergy may not be suitable because the strategic actions that manager should perform to increase value for stakeholder simultaneously are difficult to be developed. Additionally, in economic and financial unstable context, stakeholders' roles are also different because they focus on satisfying their own interests, even appropriating wealth from others (Berle \& Means, 1932; Jensen \& Meckling, 1976; Lemmon \& Lins, 2003; Donker et al., 2008; Dowell et al., 2011), which generates the conflict of interests. 
According to the above theoretical aspects, we posit that, when firms are fighting for survival, managers should prioritize some primary stakeholders over others because this strategy could help the firm to choose an appropriate stakeholder ranking and avoid the generation of conflicts of interests (Friedman \& Miles, 2006; Harrison et al., 2010) that increase the probability of falling into a financial distress situation. The second goal of this research is focused on the above idea.

We therefore propose a primary stakeholder ranking, through applying an empirical methodology, that shows the stakeholders' relative importance in the likelihood of business failures and guides firms in the stakeholder prioritization in these unstable situations. Consequently, we propose the following hypothesis:

H2: It is possible the prioritisation of primary stakeholders according to their impact on the likelihood of business failure under financial crisis contexts

\section{Research methodology}

\subsection{Sample and data}

We collected a sample of Spanish small and medium enterprises (SMEs) for the years 2006-2010, selected from the SABI database managed by Bureau van Dijk (BVD). The criteria used to select the firms were number of employees, turnover, and total assets (European Commission, 2003). Our sample was classified in two groups. First, we chose a group of firms that were in a legal failure situation in 2010. In this regard, failed firms are those which have undergone one of the following processes (Keasey \& Watson, 1987): bankruptcy (Law 22/2003 of 10 July); dissolution and/or private settlement agreements. Our sample thus included 2,277 firms that were identified as failed firms. Second, we selected another group of firms called non-failed firms (active). To that end, a matched-pair research design was used on a one-to-one basis whereby each of these failed firms were matched with a non-failed firm with a similar firm size (total assets) and from the same industry (Peursem \& Chan, 2014). We obtained a total matched sample of 4,544 firms. Some firms were then eliminated because they had missing data or gaps in the accounting. As a result, we got a final matched sample of 2,352 Spanish SMEs (see Table 1).

Table 1

Sample selection and analysis

\begin{tabular}{ll}
\hline Sample selection process & Total \\
\hline Firms in a legal failure situation & 2277 \\
Matched sample (half failed and half non-failed) & 4544 \\
Less observation with incomplete or missing data & 2192 \\
Final matched sample & 2352 \\
\hline
\end{tabular}

Moreover, the period studied covers the four years prior to legal failure ( $\mathrm{t}=2010): 2006(\mathrm{t}-4), 2007(\mathrm{t}-3), 2008(\mathrm{t}-2)$ and 2009 (t-1) in order to anticipate the dangerous financial situation as soon as possible and to make decisions to avoid it.

\subsection{Dependent and Independent Variables}

In the literature, our dependent variable, business failure, has been approached from different perspectives, such us economic, financial and legal (Altman, 1981; Jones, 1987;
Keasey \& Watson, 1991). However, this study adopts a legal perspective, which is focused on bankruptcy, termination or dissolution, as they describe a concept that is objective and rigorous (Mora, 1994; Balcaen \& Ooghe, 2006; Alfaro et al., 2008a \& b; Manzaneque et al., 2015).

In business failure prediction studies, there is no general consensus about which independent variables provide better predictions of firms' insolvencies (Altman \& Narayanan, 1997). In this sense, following the previous literature and in order to achieve our research goals, we should highlight that there is not a single variable that by itself measures exactly the impact that each stakeholder has in the firm. For this reason, we have selected various proxy variables that allow us to collect the effects of each primary stakeholders' roles according to, first, their economic and financial support to the firm and, second, their participation on the generation and distribution of firms' value added (see table 2).

Table 2

Dependent and independent variables

\begin{tabular}{|c|c|}
\hline Variables & Definition \\
\hline \multicolumn{2}{|l|}{ Dependent variable } \\
\hline Business failure (BF) & $\begin{array}{l}\text { Measured as a dummy variable that takes } \\
\text { the value } 1 \text { if the firm is considered to be } \\
\text { in a business failure situation and } 0 \\
\text { otherwise. }\end{array}$ \\
\hline \multicolumn{2}{|l|}{ Independent variable } \\
\hline Customers' economic support (C1) & $\begin{array}{l}\text { Measured as the rate of change of the } \\
\text { firm's income to the average rate of } \\
\text { change in operating income in the firm's } \\
\text { industry }\end{array}$ \\
\hline Customers' financial support I (C2) & $\begin{array}{l}\text { The ratio between volume of credit to } \\
\text { customers in the operating income to the } \\
\text { industry average }\end{array}$ \\
\hline Customers' financial support II (C3) & Average payment collection times \\
\hline $\begin{array}{l}\text { Value added generated by customers } \\
\text { (GC) }\end{array}$ & Value added to net sales \\
\hline Employees' economic support (W) & $\begin{array}{l}\text { The ratio of the cost of salaries per } \\
\text { employee to the industry average }\end{array}$ \\
\hline $\begin{array}{l}\text { Value added generated by employees } \\
\text { (GW) }\end{array}$ & $\begin{array}{l}\text { Value added to average numbers of } \\
\text { employees }\end{array}$ \\
\hline $\begin{array}{l}\text { Value added distributed to employees } \\
\text { (DW) }\end{array}$ & $\begin{array}{l}\text { Costs of wages and salaries to value } \\
\text { added }\end{array}$ \\
\hline Shareholders' financial support (SH) & Equity to the firm's total debt \\
\hline $\begin{array}{l}\text { Value added generated by } \\
\text { shareholders (GSH) }\end{array}$ & Value added to equity \\
\hline $\begin{array}{l}\text { Value added distributed to } \\
\text { shareholders (DSH) }\end{array}$ & $\begin{array}{l}\text { Measured as dividends and other } \\
\text { shareholder' profits to value added }\end{array}$ \\
\hline Suppliers' financial support (S) & $\begin{array}{l}\text { The ratio between debt to suppliers and } \\
\text { total expenditures on goods. }\end{array}$ \\
\hline $\begin{array}{l}\text { Value added generated by suppliers } \\
\text { (GS) }\end{array}$ & Measured as value added to cost of sales \\
\hline Financial creditors' support (FC) & $\begin{array}{l}\text { The ratio between financial expenses and } \\
\text { the firm's total debt }\end{array}$ \\
\hline $\begin{array}{l}\text { Value added generated by financial } \\
\text { creditors (GFC) }\end{array}$ & $\begin{array}{l}\text { The ratio between value added and } \\
\text { liabilities }\end{array}$ \\
\hline $\begin{array}{l}\text { Value added distributed to financial } \\
\text { creditors (DFC) }\end{array}$ & $\begin{array}{l}\text { The ratio between financial expenses and } \\
\text { value added }\end{array}$ \\
\hline \multicolumn{2}{|l|}{ Business failure control variables } \\
\hline Profitability (P) & $\begin{array}{l}\text { The ratio between earnings before } \\
\text { interest and taxes and equity }\end{array}$ \\
\hline Indebtedness (I) & Debt to total assets \\
\hline Liquidity (L) & Measured as current assets to liabilities \\
\hline
\end{tabular}

First, drawing upon stakeholder and resource dependence theories, firms dependent on stakeholders who have vital resources to contribute to firms' outcome and survival. In this vein, we deal with stakeholders' roles through the analysis of some stakeholders' resources related to their economic and financial support to the firm (Priego et al., 2012) that are necessary to perform firm's goal and thus survival.

According to customers, we have taken three proxy variables, from the business failure literature, that may collect how customers' role may influence firms. These variables are: 
Customers' economic support (C1) measured as the change of the firm's income to the average rate of change in operating income in the firm's industry. In that sense, there is some support in previous works for including Customers' economic support (C1) showing a negative relationship with the prediction of a business failure situation (Correa et al., 2003); Customers' financial support I (C2) measured as volume of credit to customers in the operating income to the industry average. There is no consensus, in the business failure literature, regarding the relationship between this variable and the likelihood of business failure. In this vein, some authors present a negative relationship in the manufacturing industry, in small and medium enterprises (SMEs) (Lizárraga, 1997), while other works conclude a null relationship (García et al., 1995; Somoza, 2001); And Customers' financial support II (C3) measured as average payment collection times. Von Stein and Ziegler (1984) find in a sample of German mediumsized firms that the average collection time from customers is one of the most discriminating variables analysing the firm's credit risk. Furthermore, García et al., (1995) present a positive and significant relationship between the average payment collection times and the likelihood of financial distress.

Regarding to employees, we analyse how their role impact on the firm outcome in a financial crisis situation. In order to proxy their impact on the firm, we chose the weight of salaries over the mean of the industry in order to capture whether the labour cost is hindering the long-term firm survival. Greater cost of labour could be linked to a greater ability of employees and, consequently, better capability of the firm to overcome financial crisis with better preparer employees. However, we posit that greater human cost over the mean of the sector is a sign of excessive cost of human resources and could be link to lower ability of the firm to survive under a financial crisis. Previous literature in business failure shows how impact labour cost on business failure likelihood. For instance, Padilla and Requejo (2000) show that the greater cost of salaries per employee the lower is the staff downsizing in a business failure situation.. Additionally, other authors present a positive relationship between the cost of salaries per employee and the likelihood of financial distress (Priego et al., 2012).

Shareholders' roles are analysing through their financial support measure as equity to the firm's total debt. Previous studies in financial distress indicate a consensus regarding the positive relationship between this variable and the likelihood of financial distress (Laffarga et al., 1991; Lizárraga, 1997; Correa et al., 2003).

Suppliers' roles are studied through their financial support measured as debt to suppliers and total expenditures on goods. In this line, previous business literature shows negative relationship between this variable and the likelihood of an economic and financial unstable situation (Priego et al., 2012).

Focusing on financial creditors' roles, previous researchers show that this stakeholder impact on a firm through its financial support measured as financial expenses over the firm's total debt. On the one hand, there are studies which show that the cost of debt is a good measure to analyse the business failure and presents a positive relationship with the likelihood of business failure (Correa et al., 2003; Manzaneque et al., 2015). On the other hand, other authors argue that the cost of debt does not show any empirical relationship with the firm's business failure.

Second, some variables have been also taken to measure the generation and distribution of value added by stakeholders which are involved in the firms' goals and, thus, survival (see table 2) (Altman, 1984; Lizárraga, 1997; Van Hemmen, 2000; Goxens \& Gay, 2005). In this vein, the value added is one of the most important economic indicators to analyse firms' behaviour towards its stakeholders and relationships with them (Priego et al., 2014).

Finally, we also use control variables that have been used in the business failure literature, such as profitability, indebtedness and liquidity (Mensah, 1984; Kane et al., 1996; Bunn \& Redwood, 2003) (see table 2).

All those variables are calculated with information taken from the firms' financial reporting. In this sense, it is worth highlighting the important role that financial reporting plays in periods of economic downturn because it shows the firms' economic and financial performances, which is essential for analysing business failure situations (Pinnuck, 2012). Additionally, financial reports are considered the primary source of information for stakeholders, thus they help to mitigate problems between firms and stakeholders. In light of this, financial reporting has been used in this paper as a source of data for analysing business failure situations.

\subsection{Methods employed}

In order to test the aforementioned research questions, we employ the following methods:

First, some descriptive statistics have been calculated for the failed and non-failed firms. In this case, we seek to determine whether there are differences between the two groups of firms (failed and non-failed) in terms of the primary stakeholders' roles and certain economic and financial aspects.

Second, we have applied a multivariate technique, namely a binary logistic regression model, to determine which stakeholders (through the p values) have an impact on firms facing business failure, and how (through the coefficient signs), during the 4 years prior to the business failure situation. In recent decades, several studies have shown that logistic regressions offer more methodological advantages than discriminant analysis in business prediction models. This is because logistic regressions are based on fewer restrictive hypotheses related to the distribution of independent variables (Manzaneque et al., 2015).

Third, we use the boosting classification method to analyse the order of priority in which firms should take primary stakeholders' considerations into account in a business failure situation (Alfaro et al., 2008b). In this context, the boosting method allows us to quantify the relative importance of the relationships that firms have with their stakeholders and the order in which they should be considered in setting business goals when facing a business failure situation. As Alfaro et al. (2007: 303) state, "boosting is a method that makes the most of a classifier by improving its accuracy". There are a number of possible boosting versions, however, in this investigation, we have applied the Adaboost (Freund \& Schapire, 1996), which is suitable for binary classification problems.

\subsection{Empirical Results}

\section{Descriptive statistics}

In Table 3, we present the descriptive statistic results for failed and non-failed firms using the parametric t-test (see Table 3).

The results show that failed firms are more likely than nondistressed firms to provide their customers with financial support ( $\mathrm{C} 2$ and $\mathrm{C} 3$ ) in all years, and the difference between both groups of firms is highly significant $(p<0.01)$. That is, 
Table 3

Difference of means between failed and non-failed firms

\begin{tabular}{|c|c|c|c|c|c|c|c|c|c|c|c|c|}
\hline \multirow[t]{2}{*}{ Variables } & \multicolumn{4}{|c|}{ Failed firms } & \multicolumn{4}{|c|}{ Non-failed firms } & \multicolumn{4}{|c|}{ t-test } \\
\hline & $\mathrm{t}-4$ & $\mathrm{t}-3$ & $\mathrm{t}-2$ & $\mathrm{t}-1$ & $\mathrm{t}-4$ & $\mathrm{t}-3$ & $\mathrm{t}-2$ & $\mathrm{t}-1$ & $\mathrm{t}-4$ & $\mathrm{t}-3$ & $\mathrm{t}-2$ & $\mathrm{t}-1$ \\
\hline \multicolumn{13}{|c|}{ Independent variables } \\
\hline Customers' economic support (C1) & 1.34 & 2.98 & 1.99 & 4.13 & 0.65 & 0.77 & 0.11 & 0.47 & 1.21 & $1.65^{*}$ & 1.36 & 0.99 \\
\hline Customers' financial support I (C2) & 1.81 & 1.63 & 1.45 & 1.27 & 0.74 & 0.68 & 0.71 & 0.59 & $2.39 * * *$ & $2.65 * * *$ & $3.00 * * *$ & $2,68 * * *$ \\
\hline Customers' financial support II (C3) & 109.0 & 117.53 & 125.04 & 164.42 & 92.16 & 93.48 & 100.78 & 108.16 & $2.49 * * *$ & $2.85 * * *$ & $2.01 * *$ & $3,34 * * *$ \\
\hline Value added generated by customers (GC) & 0.35 & 0.36 & 0.34 & 0.23 & 0.37 & 0.37 & 0.37 & 0.33 & -0.48 & -0.76 & $-3.38 * * *$ & $-4,89 * * *$ \\
\hline Employees' economic support (W) & 33.03 & 39.65 & 30.39 & 39.38 & 11.83 & 12.87 & 12.62 & 15.13 & $2.45 * * *$ & $1.73 *$ & 1.34 & 0,87 \\
\hline Value added generated by employees (GW) & 61.29 & 68.77 & 51.55 & 18.34 & 45.17 & 49.54 & 46.86 & 30.10 & $1.94^{*}$ & $2.31 * *$ & 2.58 & 0,35 \\
\hline Value added distributed to employees (DW) & 0.84 & 0.82 & 0.84 & 1.05 & 0.75 & 0.77 & 0.85 & 0.84 & $-2.33 * * *$ & $-1.86^{*}$ & -0.49 & $-0,66$ \\
\hline Shareholders' financial support (SH) & 1.02 & 1.55 & 0.73 & 0.69 & 1.16 & 1.26 & 1.52 & 1.52 & $3.04 * * *$ & $3.91 * * *$ & $4.27 * * *$ & $7,80 * * *$ \\
\hline Value added generated by shareholders (GSH) & 3.38 & 3.92 & 3.48 & 1.50 & 2.33 & 2.40 & 1.95 & 1.40 & $2.06 * *$ & -0.20 & -1.06 & 0,06 \\
\hline Value added distributed to shareholders (DSH) & 0.02 & 0.01 & 0.01 & 0.00 & 0.07 & 0.08 & 0.01 & 0.02 & 0.68 & 0.44 & 0.58 & $-0,45$ \\
\hline Suppliers' financial support (S) & 1.24 & 2.54 & 1.34 & 1.21 & 1.24 & 2.16 & 1.04 & 1.20 & -0.60 & 0.36 & $-5.16 * * *$ & $-3,76 * * *$ \\
\hline Value added generated by suppliers (GS) & 2.04 & 1.90 & 2.17 & 2.13 & 1.69 & 1.73 & 1.89 & 0.62 & -1.46 & -1.06 & $-2.10 * *$ & $-6,94 * *$ \\
\hline Financial creditors' support (FC) & 0.08 & 0.08 & 0.02 & 0.08 & 0.05 & 0.08 & 0.10 & 0.08 & $-1.91 *$ & $-2.03 * *$ & 0.811 & $4,86^{* * * *}$ \\
\hline Value added generated by financial creditors (GFC) & 1.09 & 1.12 & 1.05 & 0.72 & 1.13 & 1.17 & 1.36 & 0.54 & $6.07 * * *$ & $6.46^{* * *}$ & $1.66^{*}$ & $-8,31 * * *$ \\
\hline Value added distributed to financial creditors (DFC) & 0.06 & 0.07 & 0.04 & 0.06 & 0.04 & 0.06 & 0.06 & 0.03 & $2.76^{* * *}$ & 1.18 & -0.07 & 0,75 \\
\hline \multicolumn{13}{|c|}{ Business failure control variables } \\
\hline Profitability (P) & 0.02 & 0.23 & -0.74 & -0.58 & 0.04 & 0.32 & 0.14 & 0.03 & $-3.65 * * *$ & $-2.73 * * *$ & -1.05 & $-0,69$ \\
\hline Indebtedness (I) & 6.79 & 6.79 & 7.14 & 2.6 & 5.10 & 4.67 & 3.17 & 2.40 & $-3.84 * * *$ & -0.82 & $-2.85 * * *$ & $-6,82 * * *$ \\
\hline Liquidity (L) & 0.37 & 0.28 & 0.24 & 0.17 & 0.39 & 0.43 & 0.48 & 0.56 & 1.24 & 1.39 & $2.60 * * *$ & 0,29 \\
\hline
\end{tabular}

$* * *$ Significant at the $1 \%$ level; $* *$ Significant at the $5 \%$ level; * Significant at the $10 \%$ level.

Note: a) Independent variables: Customers' economic support= change in the income of the company/ average rate of change in operating income for the sector to which the company belongs; Customers' financial support I= credit to customers in operating income/ average for the sector; Customers' financial support II= average collection time from customers; Value added generated by customers = value added / net sales; Employees' economic support =Cost of salaries per employee / mean of the cost of salaries per employee in the industry sector in which the firm operates; Value added generated by employees = value added/average numbers of employees; Value added distributed to employees $=$ costs of wages and salaries to value added; Shareholders' financial support $=$ equity/total debt; Value added generated by shareholders $=$ value added / equity; Value added distributed to shareholders = dividends and other shareholder profits / value added; Suppliers' financial support= debt to suppliers / total expenditures for purchases of goods; Value added generated by suppliers= value added/ cost of sales; Financial creditors' support = financial expenses/firm's total debt; Value added generated by financial creditors = value added to liabilities; Value added distributed to financial creditors $=$ financial expenses to Value added; b) Control variables: Profitability= earnings before interest and taxes /equity; Indebtedness= debt to total assets; and liquidity= current assets to liabilities; c) The table shows the means of the variables in both groups of firms (failed and non-failed firms) and the difference of means between the two groups of firms using the parametric t-test.

failed firms offer more credit to their customers and are more flexible in terms of payment collection times, thereby increasing the risk of business failure. Regarding the value added generated by customers (GC), failed firms generate less from their net sales than non-failed firms during the years $\mathrm{t}-2$ and $\mathrm{t}-1$, and this is significant $(\mathrm{p}<0.01)$.

With regard to employees impact on business failure likelihood (W), measured as the cost of salaries relative to the industry mean, this is higher for the failed firms group during the years $\mathrm{t}-4$ and $\mathrm{t}-3(\mathrm{p}<0.01$ and 0.1$)$. Moreover, value added generated by and distributed to employees (GW and DW) show significant differences between the two groups in $\mathrm{t}-4$ and $\mathrm{t}-3$.

With respect to shareholders' financial support ( $\mathrm{SH})$, the statistics reveal that failed and non-failed firms significantly differ $(p<0.01)$ : failed firms have less equity relative to the firm's total debt over the entire period under study. Thus, this situation could increase the risk of business failure.

In relation to suppliers' financial support (S) and value added generated by suppliers (GS), we observe significant differences at $1 \%$ and $5 \%$ in the years $\mathrm{t}-2$ and $\mathrm{t}-1$. In both cases, the failed firms have higher values.

For financial creditors' support (FC), the results show that non-failed firms report more support from t- 3 to $t-1$ and less in $\mathrm{t}-4$ than failed firms, and this is significant in all years expect $\mathrm{t}-2$. In terms of value added generated by financial creditors (GFC), non-failed firms show a higher contribution than failed firms from $\mathrm{t}-4$ to $\mathrm{t}-2$.

Finally, regarding the business failure control variables, profitability and liquidity are higher and indebtedness is lower in non-failed firms than in failed firms. These results are consistent with those obtained by Mensah (1984) and Kane et al. (1996) showing that high levels of indebtedness (I) and low levels of profitability (P) and liquidity (L) are related to business failure.

We also analyse the correlation matrix; the results are not tabulated here but are available from the authors upon re- quest. Correlations between our variables do not exceed 0.7 ; correlations greater than this are considered a problem in multiple regressions (Tabachnick \& Fidell, 1996). Thus, there are not multicollinearity problems.

\section{Logistic regression models}

Using a binary logistic regression methodology, a different prediction model has been developed for each year of the study period, to determine which primary stakeholders influence the firm's business failure likelihood, and how. The results of the logistic regression models are shown in Table 4.

With respect to customers, the logit model shows that failure is positively related to the customers' financial support II (C3) (significant at the 0.01 and 0.05 levels in years $t-1$ and $\mathrm{t}-3$ ) and negatively related to the value added generated by customers (GC) (significant at the 0.1 level in t- 1 and at the 0.05 level in $\mathrm{t}-3$ and $\mathrm{t}-4$ ). This suggests that firms should pay attention to the average customer payment collection times, since the greater the value of this variable is, the larger number of receivables and, thus, the greater the likelihood of failure (John, 1993). Moreover, the results highlight the need to consider the contribution made by customer sales to the value added because they increase the probabilities of firm survival. These results are consistent with some works which argue the positive effects of firm-customers relationship on financial performance (Berman et al., 1999) and on reducing the likelihood of financial distress (Priego et al., 2014). For this reason, firms should develop strategies focused on securing the long-term loyalty of customers through understanding customers' need and behaviours (Campbell, 2003; Harrison et al., 2010) and setting quality and safety product policies (Berman et al., 1999), since they are a key stakeholder in helping to prevent business failure situations. Thus, customers play an important role in the likelihood of business failure.

With regard to employees, the results show that employees' economic support (W) is positively related with business fail- 
Table 4

Binary logistic regression models

\begin{tabular}{|c|c|c|c|c|}
\hline \multicolumn{5}{|c|}{ Variable dependent: Non-failure firms (0) vs. Failure firms (1) } \\
\hline Variables independents & $\mathrm{t}-1$ & $\mathrm{t}-2$ & $\mathrm{t}-3$ & $\mathrm{t}-4$ \\
\hline & $\begin{array}{c}\text { Coefficients } \\
\text { (Wald } \chi^{2} \\
\text { Statistic) }\end{array}$ & $\begin{array}{c}\text { Coefficients } \\
\text { (Wald } \chi^{2} \\
\text { Statistic) }\end{array}$ & $\begin{array}{c}\text { Coefficients } \\
\text { (Wald } \chi^{2} \\
\text { Statistic) }\end{array}$ & $\begin{array}{c}\text { Coefficients } \\
\text { (Wald } \chi^{2} \\
\text { Statistic) }\end{array}$ \\
\hline Customers' financial & 0.002 & 0.001 & 0.001 & \\
\hline support II (C3) & $(26.187) * * *$ & $(8.433)$ & $(9.068)^{* * *}$ & \\
\hline Value added gener-ated by & -0.295 & -0.293 & -0.724 & -5.865 \\
\hline & $(4.526)^{*}$ & $(2.943)$ & $(10.599)^{* *}$ & $(6.874)^{* *}$ \\
\hline Employees' economic & 0.003 & 0.003 & & \\
\hline & $(2.875) * * *$ & $(3.672)^{* *}$ & & \\
\hline $\begin{array}{l}\text { Value added generated by } \\
\text { employees (GW) }\end{array}$ & $\begin{array}{c}-0.005 \\
(14.611)^{* * * *}\end{array}$ & $\begin{array}{c}0.002 \\
(6.794)^{* *}\end{array}$ & $\begin{array}{c}0.005 \\
(28.709)^{* * *}\end{array}$ & $\begin{array}{c}0.006 \\
(28.525)^{* * *}\end{array}$ \\
\hline $\begin{array}{l}\text { Value added distributed to } \\
\text { employees (DW) }\end{array}$ & & $\begin{array}{c}-0.215 \\
(5.371)^{*}\end{array}$ & & $\begin{array}{c}1.116 \\
(7.353)^{* *}\end{array}$ \\
\hline $\begin{array}{l}\text { Shareholders' financial } \\
\text { support (SH) }\end{array}$ & & $\begin{array}{c}-0.094 \\
(8.967) * *\end{array}$ & $\begin{array}{c}-0.090 \\
(9.018) * *\end{array}$ & \\
\hline $\begin{array}{l}\text { Value added distributed to } \\
\text { shareholders (DSH) }\end{array}$ & & $\begin{array}{c}-0.211 \\
(5.902) *\end{array}$ & & $\begin{array}{c}1.121 \\
(7.240)^{* *}\end{array}$ \\
\hline Suppliers (S) & $\begin{array}{c}0.0820 \\
(3.844)^{*}\end{array}$ & $\begin{array}{c}0.058 \\
(3.671)\end{array}$ & & \\
\hline $\begin{array}{l}\text { Value added generated by } \\
\text { financial creditors (GFC) }\end{array}$ & $\begin{array}{c}0.055 \\
(3.415)\end{array}$ & $\begin{array}{c}0.088 \\
(4.195)^{*}\end{array}$ & $\begin{array}{c}0.158 \\
(11.431)^{* * * *}\end{array}$ & $\begin{array}{c}0.078 \\
(4.006) *\end{array}$ \\
\hline $\begin{array}{l}\text { Value added distributed to } \\
\text { financial creditors (DFC) }\end{array}$ & & $\begin{array}{l}-0.128 \\
(4.195)\end{array}$ & & $\begin{array}{c}1.729 \\
(3.220)\end{array}$ \\
\hline Profitability (P) & $\begin{array}{c}-0.070 \\
(4.323)^{*}\end{array}$ & $\begin{array}{c}-0.178 \\
(12.263)^{* * *}\end{array}$ & $\begin{array}{c}-0.138 \\
(7.688)^{* *}\end{array}$ & $\begin{array}{c}-0.088 \\
(7.614)^{* *}\end{array}$ \\
\hline Indebtedness (I) & & $\begin{array}{c}0.005 \\
(3.813)\end{array}$ & & \\
\hline Liquidity (L) & $\begin{array}{c}-0.711 \\
(31.613)^{* * *}\end{array}$ & $\begin{array}{c}-0.156 \\
(3.955)^{*}\end{array}$ & & \\
\hline Constants & $\begin{array}{l}-0.072 \\
(0.450)\end{array}$ & $\begin{array}{l}-0.168 \\
(1.535)\end{array}$ & $\begin{array}{l}-0.249 \\
(1.507)\end{array}$ & $\begin{array}{c}-1.413 \\
(12.873)^{* * *}\end{array}$ \\
\hline$\chi^{2}$ (sig.) & $184.113^{* * *}$ & $114.181^{* * *}$ & $107.306^{* * * *}$ & $94.329 * * *$ \\
\hline$-2 \log$ verisimilitude & 1990 & 2060 & 2066 & 2079 \\
\hline$R^{2}$ of $\operatorname{Cox}$ & 0.111 & 0.070 & 0.066 & 0.058 \\
\hline$R^{2}$ of Nagelkerke & 0.147 & 0.093 & 0.088 & 0.078 \\
\hline $\begin{array}{l}* * * \text { Significant at the } 1 \% \\
\text { * Significant at the } 10 \% \text { le } \\
\text { Note: a) Independent var } \\
\text { of the company/ average } \\
\text { company belongs; Custor } \\
\text { income/ average for the } \\
\text { time from customers; Val } \\
\text { Employees' economic sup } \\
\text { salaries per employee in } \\
\text { generated by employees } \\
\text { distributed to employees } \\
\text { financial support= equity } \\
\text { added / equity; Value } \\
\text { shareholder profits / val } \\
\text { total expenditures for pur } \\
\text { added/ cost of sales; Fina } \\
\text { Value added generated by } \\
\text { distributed to financial } \\
\text { variables: Profitability= } \\
\text { debt to total assets; and li }\end{array}$ & $\begin{array}{l}\text { level; ** Sign } \\
\text { evel. } \\
\text { riables: Custo } \\
\text { rate of chang } \\
\text { mers' financi } \\
\text { sector; Cust } \\
\text { lue added gen } \\
\text { pport = Cost } \\
\text { the industry } \\
\text { = value adde } \\
\text { = costs of we } \\
\text { y/total debt; } \\
\text { added distrib } \\
\text { ue added; Su } \\
\text { rchases of goc } \\
\text { incial creditor } \\
\text { y financial cr } \\
\text { creditors = fi } \\
\text { earnings bef }\end{array}$ & $\begin{array}{l}\text { cant at the } 5 \\
\text { ers' economic } \\
\text { n operating } \\
\text { support I = } \\
\text { hers' financia } \\
\text { ated by custc } \\
\text { salaries per } \\
\text { ctor in which } \\
\text { average nun } \\
\text { es and salari } \\
\text { lue added ge } \\
\text { ted to share } \\
\text { liers' fi-nanc } \\
\text { s; Value adde } \\
\text { support = fin } \\
\text { itors = value } \\
\text { ancial expens }\end{array}$ & $\begin{array}{l}\text { vel; } \\
\text { port = chan } \\
\text { it to custom } \\
\text { pport II = a } \\
\text { s = value a } \\
\text { loyee / mea } \\
\text { firm opera } \\
\text { of employ } \\
\text { value adde } \\
\text { ted by shar } \\
\text { ders = divi } \\
\text { upport = de } \\
\text { enerated by } \\
\text { al expenses, } \\
\text { ed to liabilit } \\
\text { to value ad }\end{array}$ & $\begin{array}{l}\text { n the income } \\
\text { to which the } \\
\text { in operating } \\
\text { ge collection } \\
\text { d / net sales; } \\
\text { f the cost of } \\
\text { Value added } \\
\text { Value added } \\
\text { Shareholders' } \\
\text { ders = value } \\
\text { ls and other } \\
\text { o suppliers / } \\
\text { pliers = value } \\
\text { n's total debt; } \\
\text { Value added } \\
\text {; b) Control } \\
\text { debtedness= }\end{array}$ \\
\hline
\end{tabular}

ure in t-1 (significant at the 0.01 level) and t-2 (significant at the 0.05 level). Thus, the higher the cost of salaries per employee relative to the industry mean, the higher the probability of a business failure situation. These results are in line with some works which highlight that, one of the reasons of incurring a business failure situation, can be caused because the excessive remuneration policies through agreements with indemnity or golden parachute provisions that firms had to paid to employees (Goktan et al., 2018). According to the explanatory variable value added generated by employees (GW) which indicates the productivity of the firm, we suppose that a higher value of this variable means than the firm is less likely to experience business failure. Our findings are consistent with this assumption one year before business failure (t-1) (significant at the 0.01 level), pointing to employees as a stakeholder with great potential impact on the levels of productivity and, therefore, on the value chain and competitiveness of the SMEs (Cegarra-Leiva et al., 2012; Herrera et al., 2016), reducing the likelihood of business failure. However, this situation happens only when employees are close to the business failure because they see their work placement endangered due to the firm's economic and financial instabilities and try to fight for the firm's survival. On the other hand, the variable value added distributed to employees (DW) shows a positive relationship with the likelihood of business failure in t-4 (significant at the 0.05 level) and negative in $\mathrm{t}-2$ (significant at the 0.1 level) showing that the inappropriate remuneration policies guide the firm to an economic and financial unstable situation. Thus, with respect to the employees' roles, the firm should consider them in the firms' goals because they are important stakeholders that could affect the likelihood of business failure.

In the case of shareholders, the models show that shareholders' financial support ( $\mathrm{SH}$ ) has a negative relationship (significant at the 0.05 level in $\mathrm{t}-2$ and $\mathrm{t}-3$ ) with a business failure situation. In this sense, it would seem that shareholders' high levels of involvement with the firm increases the probabilities of survival. This is consistent with Russo \& Tencati (2009), who argue from a stakeholder theory perspective that shareholders in SMEs develop a closer, more honest and more flexible relationship with the firm and other stakeholders than those in non-SMEs, in order to minimize the conflicts of interests that could affect business survival. In this vein, SMEs' shareholders orient the firms' strategies and objectives in a socially responsible way in order to take into account all stakeholders' interests. This helps generate long-term business growth (Moore \& Manring, 2009) and therefore helps ensure the survival of the firm. Regarding value added, the literature argues that shareholders encourage the firm to undertake profitable projects, use resources efficiently, improve the firms' competitive advantage, etc. (Pérez-Carballo, 2001) in order to increase the value added, so that they can then participate in its distribution. This is consistent with the result that value added distributed to shareholders (DSH) (significant at the 0.1 level) appears two years before business failure. Thus, we suggest that the firm should develop relationships with the shareholders and take into account their participation in the distribution of value added in $t-2$ and shareholders' financial support in $\mathrm{t}-2$ and $\mathrm{t}-3$, as they may reduce the probability of business failure.

For the independent variable suppliers' financial support (S), we assume that when suppliers collaborate with firms by providing loans, this helps to avoid a business failure situation (San-José \& Cowton, 2009). However, we cannot confirm this relationship with suppliers because the results are not as expected.

On the other hand, we might argue that SMEs' management may be more opaque and more prone to concentration risk, thus driving up financial costs and/or making it more difficult to access funding from financial creditors in the medium and long-term (Casasola \& Cardone, 2009), which could in turn lead to business failure. However, the results do not support this assumption.

With regard to the economic and financial control variables, the results show that greater profitability (P) levels are negatively related to the probability of business failure for the whole period under study (Manzaneque et al., 2015). And, finally, high liquidity (L) levels also present a negative relationship with business failure one and two years before failure.

Regarding the test for checking the goodness of fit of the models, such as $-2 \log$ verisimilitude, Cox and Snell's $R^{2}$ and Nagelkerke's $R^{2}$, the results show that the models estimated are appropriate and useful for business failure prediction.

Regarding Hypothesis 1, we can confirm that customers' financial support II (C3) and employees' economic sup- 
port (W) have a positive relationship with business failure, whereas value added generated by customers (GC), value added generated by employees (GW), shareholders' financial support (SH), profitability (P) and liquidity (L) impact negatively on the likelihood of a business failure situation.

In brief, we can say that the logistic regression analysis has provided useful information with which to study business failure related to the primary stakeholders' roles through the analysis of stakeholders' resources such as their economic and financial support to the firm or the generation or distribution of added value. Our findings indicate that firms should address their relationships with customers, employees and shareholders, considering their interests and demands, because these stakeholders are critical to preventing business failure.

\section{The relative importance of the variables}

In this section, we analyse the relative importance of the predictor variables by means of the boosting method (Table 5). We do so for a number of different reasons: first, boosting gives more accurate results than logit, both in training and test sets, due to the fact that it manages to determine the relative importance of some variables that logit cannot identify; and second, this methodology can be used to test our second research question, which is related to the prioritization of primary stakeholders in order to show their relative importance in the firms' outcomes and, thus, in a business failure situation.

Table 5

Relative importance of variables

\begin{tabular}{|c|c|c|c|c|c|}
\hline Variable & $\mathrm{t}-1$ & $\mathrm{t}-2$ & $\mathrm{t}-3$ & $\mathrm{t}-4$ & $\begin{array}{c}\text { Average } \\
\text { rank }\end{array}$ \\
\hline $\begin{array}{l}\text { Customers' financial support II (C3) } \\
\text { (C) }\end{array}$ & 2 & 2 & 4 & 1 & 2.25 \\
\hline Value added generated by employees (GW) & 4 & 5 & 2 & 4 & 3.75 \\
\hline Liquidity (L) & 1 & 3 & 8 & 6 & 4.5 \\
\hline Employees' economic support (W) & 5 & 4 & 5 & 5 & 4.75 \\
\hline Value added generated by shareholders (GSH) & 6 & 11 & 1 & 10 & 7 \\
\hline Customers' economic support (C1) & 12 & 9 & 6 & 3 & 7.5 \\
\hline Financial creditors' support (FC) & 17 & 1 & 3 & 15 & 9 \\
\hline Value added generated by financial creditors (GFC) & 11 & 7 & 7 & 11 & 9 \\
\hline Value added generated by suppliers (GS) & 8 & 10 & 14 & 7 & 9.75 \\
\hline Customers' financial support II (C2) & 7 & 12 & 12 & 8 & 9.86 \\
\hline Profitability (P) & 3 & 16 & 16 & 6 & 10.25 \\
\hline Value added distributed to employees (DW) & 15 & 6 & 13 & 9 & 10.75 \\
\hline Value added distributed to shareholders (DSH) & 10 & 8 & 9 & 16 & 10.75 \\
\hline Shareholders' financial support (SH) & 9 & 14 & 9 & 13 & 11.25 \\
\hline Value added generated by customers (GC) & 8 & 10 & 15 & 17 & 12.98 \\
\hline Indebtedness (I) & 14 & 15 & 11 & 14 & 13.5 \\
\hline Suppliers' financial support (S) & 18 & 18 & 18 & 2 & 14 \\
\hline Value added distributed to financial creditors (DFC) & 16 & 18 & 17 & 18 & 17.25 \\
\hline
\end{tabular}

Note: a) Independent variables: Customers' economic support= change in the income of the company/ average rate of change in operating income for the sector to which the company belongs; Customers' financial support I= credit to customers in operating income/ average for the sector; Customers' financial support II= average collection time from customers; Value added generated by customers = value added / net sales; Employees' economic support $=$ Cost of salaries per employee $/$ mean of the cost of salaries per employee in the industry sector in which the firm operates; Value added generated by employees $=$ value added/average numbers of employees; Value added distributed to employees $=$ costs of wages and salaries to value added; Shareholders' financial support $=$ equity/total debt; Value added generated by shareholders = value added / equity; Value Suppliers' financial support $=$ debt to suppliers $/$ total expenditures for purchases of goods; Value added generated by suppliers = value added/ cost of sales; Financial creditors support = financial expenses/firm's total debt; Value added generated by financial creditors $=$ value added to liabilities; Value added distributed to financial creditors $=$ financial expenses to value added; b) Control variables: Profitability $=$ earnings before interest and taxes /equity; Indebtedness = debt to total assets; and liquidity = current assets to liabilities.

Table 5 shows the average rank of the variables over the whole period, which is calculated by the relative importance of the variables in the years before the business failure. The results present the average rank, from the highest to the lowest relative importance of the primary stakeholders that firms should consider when setting firms' goals.
Accordingly, the most important variables for testing our second research question regarding how firms should prioritize their primary stakeholders in the years preceding a business failure situation are the following: customers' financial support II (C3); value added generated by employees (GW); liquidity (L); and employees' economic support (W). On the other hand, the least important variables are value added distributed to financial creditors (DFC) and suppliers' financial support (S). Therefore, we can accept hypothesis 2 which highlights that it is possible the prioritisation of primary stakeholders related to their impact on the likelihood of business failure.

Therefore, SMEs should manage their relationships with customers and employees more carefully than those with other stakeholders, because they will have a more relevant impact on the firm's outcome in the years leading up to business failure. Our findings are consistent with those of Neville \& Menguc (2006), who show that firms dependent on their customers because they provide the revenue to sustain the firm's profit-making. Berman et al. (1999) also show that customer behaviour is related to the firm's performance and so this stakeholder should be considered in the firm's strategy and business goals. In this regard, firm should consider customers as important stakeholders that could affect the likelihood of business failure, namely firm should control and manage the average customer collection times.

Employees are also considered a vital resource for the success of the firm because of their work and human capital (Neville \& Menguc, 2006). For this reason, firms should provide employees with support, interesting employment and effective remuneration policy that does not harm the firm and ensure their collaboration with the firm. Regarding the control variables, we find that liquidity is a key variable to classify a firm as healthy. Thus, firms with greater values of this variable have a greater likelihood of survival. These results are consistent with the logistic regression models because all these variables are significantly related with a business failure situation.

Regarding our second research question, we can argue that boosting methodology has helped to accurately identify the order of priority in which firms should rank the key primary stakeholders' considerations into account in their firm goals, because they help ensure firm's outcomes and, thus, survival and success for SMEs. Furthermore, our findings are in line with other works which highlight that customers and employees should be considered in the first places of stakeholders' ranking because of their relative importance in the firm (Preston \& Sapienza, 1990; Berman et al., 1999; Dunham et al., 2006; Sen \& Cowley, 2013).

\section{Goodness of fit}

In order to validate the accuracy of the aforementioned business failure prediction logit and boosting models, we have estimated the success and global error rates, and the type I and type II errors for each model over the whole period. To estimate the real accuracy, the final matched sample of 2,352 firms was divided into two sets: i) 1,568 firms $(66.66 \%)$ were included as a training set sample to build the classifier and; ii) the remaining 784 firms (33.33\%) formed the test set sample to check the prediction accuracy. This was done because the results in the training set tend to overestimate accuracy and underestimate errors.

As can be seen in Table 6 , the results show that the percentage of success increases as we get closer to the year of the business failure. These results are in line with previous business failure prediction studies (Correa et al., 2003; Labatut et al., 2009). The boosting methodology achieved the best 
Table 6

Accuracy and Global Error Rates

\begin{tabular}{|c|c|c|c|c|c|c|c|c|}
\hline \multirow[t]{3}{*}{ Period } & \multirow[b]{3}{*}{ Accuracy } & \multirow[b]{3}{*}{ Global error } & \multicolumn{6}{|c|}{ Success and Global Error rates } \\
\hline & & & \multicolumn{3}{|c|}{ Testing } & \multicolumn{3}{|c|}{ Training } \\
\hline & & & Type I & Type II & Success & Global error & Type I & Type II \\
\hline \multicolumn{9}{|l|}{ Year t-1 } \\
\hline Logit & $64.286 \%$ & $35.755 \%$ & $33.673 \%$ & $37.755 \%$ & $75.319 \%$ & $24.681 \%$ & $21.811 \%$ & $27.551 \%$ \\
\hline Boosting & $74.617 \%$ & $25.382 \%$ & $21.173 \%$ & $29.591 \%$ & $97.258 \%$ & $2.742 \%$ & $2.423 \%$ & $3.061 \%$ \\
\hline \multicolumn{9}{|l|}{ Year t-2 } \\
\hline Logit & $60.331 \%$ & $39.669 \%$ & $33.928 \%$ & $45.408 \%$ & $61.798 \%$ & $38.201 \%$ & $31.122 \%$ & $45.280 \%$ \\
\hline Boosting & $70.536 \%$ & $29.464 \%$ & $31.887 \%$ & $27.041 \%$ & $94.834 \%$ & $5.166 \%$ & $5.102 \%$ & $5.230 \%$ \\
\hline \multicolumn{9}{|l|}{ Year t-3 } \\
\hline Logit & $59.543 \%$ & $40.051 \%$ & $31.122 \%$ & $48.980 \%$ & $61.542 \%$ & $38.457 \%$ & $31.505 \%$ & $45.408 \%$ \\
\hline Boosting & $67.091 \%$ & $32.908 \%$ & $35.459 \%$ & $30.357 \%$ & $91.964 \%$ & $8.035 \%$ & $6.887 \%$ & $9.183 \%$ \\
\hline \multicolumn{9}{|l|}{ Year t-4 } \\
\hline Logit & $60.842 \%$ & $39.159 \%$ & $26.276 \%$ & $52.041 \%$ & $61.224 \%$ & $77.551 \%$ & $28.699 \%$ & $48.852 \%$ \\
\hline Boosting & $68.877 \%$ & $31.122 \%$ & $29.082 \%$ & $33.163 \%$ & $95.727 \%$ & $4.273 \%$ & $3.699 \%$ & $4.846 \%$ \\
\hline
\end{tabular}

Note: Type I error: classification as a non-failed firm when it is a failed firm; type II error: classification as failed firm when it is a non-failed firm

accuracy and the lowest error rates in both the training and test sets for the entire period. Thus, we can say that boosting methodology is suitable for business failure prediction and allows us to rank the stakeholders according their importance under unstable situation.

\section{Conclusions}

Taking into consideration previous literature, this paper explores the role of primary stakeholders when firms suffer economic and/or financial difficulties. Also, an order of prioritization of these primary stakeholders is proposed in order to avoid bankruptcy. To do this, an empirical analysis was carried out over a sample of 2,352 Spanish SMEs, of which half had been involved in a legal business failure situation. A multivariate technique, namely a binary logistic regression model, was applied to test which primary stakeholders influence firms in a business failure situation and how they do so. Following this, a boosting method was carried out to test the prioritisation (i.e. the relative importance of our independent variables) in which firms should take into account the primary stakeholders' roles when setting firm goals to anticipate a business failure situation.

We obtain a number of interesting results relating to the view that stakeholders should be consider in order to anticipate a business failure situation. First, in line with other related research (Hummels, 1998; Mellahi \& Wilkinson, 2004; Carter \& Auken, 2006; James, 2016), the findings show that the role of stakeholders is significantly related to the likelihood of a business failure situation. We highlight the significant effects that certain primary stakeholders' roles have in economic and financial difficult situations. Specifically, firms should take into account the roles of those primary stakeholders, by analysing their vital resources, and true influence on the firms' outcomes and, thus, on the likelihood of business failure. Regarding the logistic regression models, we find that customers and employees have a significant and positive relationship with business failure likelihood. Accordingly, firms should pay attention to the average payment collection times by customers one and three years before failure because the greater number of receivables the less performance generates the firm. Furthermore, the cost of employees' salaries one and two years before failure should be managed because an incorrect remuneration policy may lead the firm towards an impasse. Nevertheless, the results show that value added generated by customers and employees and shareholders' equity in relation to the firm's total debt have a significant and negative relationship with business failure. In conclusion, net sales to customers over the whole period of study, employees' participation in the firms' productivity one year before failure and the shareholders' financial involvement in the firm two and three years before failure have to be considered as key stakeholder resources that impact on the likelihood of a business failure situation.

Second, in contrast to other studies which consider that firms should consider different stakeholders simultaneously (Tantalo \& Priem, 2016), the authors argue that, in macroeconomic unstable situations, firms may prioritize stakeholders' roles in order to avoid the emergence of a conflict of interests that impact on the firms' outcomes and increases the likelihood of business failure. Accordingly, when the firms' outcomes are critical, stakeholders fight to obtain them, and conflict of interests emerges. With this regard, due to the fact that stakeholders' roles may be divergent in business failure situations, we present, through the boosting method, exactly how firms may prioritize primary stakeholders, through analysing their vital resources, in order to avoid the emergence of conflicts of interests that may increase the likelihood of business failure. In so doing, the results present a ranking where firms may consider customers and employees as key primary stakeholders when firms' goals are set in certain years before business failure. Namely, firm should focus on managing the average customer collection time and setting an adequate remuneration policy since they are main stakeholder resources that impact on the likelihood of business failure. This order of priority is in line with a previous study from Robert Wood, in 1947, (Preston \& Sapienza, 1990), who suggests that customers and employees should rank in the first and second order of importance of the stakeholders that influence firms and firms' performance (Berman et al., 1999). In this line, Dunham et al. (2006) and Sen and Cowley (2013) also consider employees and customers as salience stakeholders that have to be ranked in the highest positions because of their impact on firms. Thus, these findings can help managers to take decisions that reduce the risk of bankruptcy in unstable macroeconomic situations.

The contributions of our findings are twofold important. From the point of view of the theoretical contributions, this study complements previous literature on stakeholders. While prior research show that stakeholders' roles impact on 
firm outcomes (Hillman \& Keim, 2001; Choi \& Wang, 2009), this work highlights that, namely, primary stakeholders' roles impact on firm outcomes in unstable economic and financial situations. Furthermore, this study also contributes to the stakeholder literature suggesting a stakeholder ranking related to the impact on the likelihood of business failure. Therefore, we address the call for more studies (Sen \& Cowley, 2013) on proposing a primary stakeholder ranking in unstable macroeconomic situations.

In addition, our findings also help to expand the stakeholder management literature with respect to firm outcomes and business failure (James, 2016), showing that managers should not treat and focus on all stakeholders equally through synergies, but in fact with a particular order of priority when firms are in economic and financial difficult situations. Moreover, our paper integrates stakeholder and resource dependence theories to analyse how firms should manage and rank primary stakeholders, thought analysing their resources, which are needed to perform the firms' goal and affect the likelihood of business failure.

From the point of view of the methodological contributions, in the business failure literature, this paper is, as far as we know, the first to analyse the relationship between business failure and SMEs' primary stakeholders, incorporating boosting methodology into prediction models. Thus, this study provides a guide to firm management, showing the correct ranking for considering stakeholders' roles in a prediction of a business failure in unstable macroeconomic situations.

Finally, the findings of our study have some relevant implications. According to the high percentage of failure in SMEs, this work answers the call of the academic community that studies the stakeholders' roles and their impact on the firms' outcomes in unstable situations. In so doing, this work links the research related to stakeholders and business failure SMEs in unstable situations. Besides, our findings offer researches a new perspective for ranking primary stakeholders in a prediction of a business failure situation and these implications can apply in contexts or scenarios with similar stakeholder management relations. The practical implications for managers highlight that this study provides guidelines about how to manage primary stakeholders and which of them deserve broad consideration in order to reduce the likelihood of incurring a business failure situation. Accordingly, managers should take primary stakeholders into consideration in the proposed ranking when developing management strategies and firm goals in unstable macroeconomic situations, as their collaboration may help firms to anticipate a business failure situation. Furthermore, the findings provide an interesting point of view to investors and regulators who may assess the roles that stakeholders have in the capital markets in business failure situations. Thus, our work may be considered as a useful tool to help guide policy-makers and firms in unstable macroeconomic situations.

Our work has its limitations that indicate future lines of research. First, this paper has used only ratios from the annual reports as explanatory variables, so it could be interesting to use other non-financial variables such as corporate social responsibility, information about the stakeholders and/or firm characteristics such as age, industry, etc. Second, we assume that only the primary stakeholders affect firm survival. However, it could be interesting to analyse the secondary stakeholders or to classify them differently, in order to understand how they relate to a business failure situation. Third, we have only studied business failure from the legal point of view, thus, an extension of this research may be to consider a broader business failure perspective, for instance, economic and financial failure. And finally, future research could also extend the period under analysis, for example, taking into consideration the years following the global financial crisis and trying to compare the periods before and after the crisis to better understand the roles that stakeholders have in both.

\section{Acknowledgements}

We would like to acknowledge the helpful comments and insightful suggestions from conference participants at the 2017 International Conference on Business-Clute Institute in Stockholm, Sweden and at the 2017 XXV Congress EBEN, in Cuenca, Spain.

\section{Conflicts of interest}

The authors have no conflicts of interest to declare.

\section{References}

Agle, B. R., Donaldson, T., Freeman, R. E., Jensen, M. C., Mitchell, R. K. \& Wood, D. J. (2008). Dialogue: Toward superior stakeholder theory. Business Ethics Quarterly, 18(2), 153-190. https://doi.org/10.5840/beq200818214

Alfaro, E., Gámez, M. \& García, N. (2007). Multiclass corporate failure prediction by Adaboost. International Advances in Economic Research, 13(3), 301-312. https://doi. org/10.1007/s11294-007-9090-2

Alfaro, E., Gámez, M. \& García, N. (2008). Linear discriminant analysis versus Adaboost for failure forecasting. Spanish Journal of Financing and Accounting, 37(137), 13-32.

Alfaro, E., García, N., Gámez, M. \& Elizondo, D. (2008). Bankruptcy forecasting: An empirical comparison of AdaBoost and neural networks. Decision Support Systems, 45, 110-122. https://doi.org/10.1016/j.dss.2007.12.002

Altman, E. I. (1968). Financial ratios, discriminant analysis and the prediction of corporate bankruptcy. The Journal of Finance, 23(4), 589-609. https://doi.org/10.1111/j. 1540-6261.1968.tb00843.x

Altman, E. I., Haldeman, R. G., \& Narayanan, P. (1977). ZETATM analysis A new model to identify bankruptcy risk of corporations. Journal of Banking \& Finance, 1(1), 29-54. https://doi.org/10.1016/0378-4266(77)90017-6

Altman, E. I. (1981). Financial handbook. 5ž Edition John Wiley \& Son, New York.

Altman, E. I. (1984). A further empirical investigation of the bankruptcy cost question. The Journal of Finance, 39(4), 1067-1089. https://doi.org/10.2307/2327613

Altman, E. I., \& Narayanan, P. (1997). An international survey of business failure classification models. Financial Markets, Institutions \& Instruments, 6(2), 1-57. https://doi.org/ 10.1111/1468-0416.00010

Balcaen, S. \& Ooghe, H. (2006). 35 Years of studies on business failure: an overview of the classic statistical methodologies and their related problems. The British Accounting Review, 38(1), 63-93. https://doi.org/10.1016/j.bar.2005. 09.001

Barney, J. B., \& Arikan, A. M. (2001). The resource-based view: Origins and implications. Handbook of Strategic Management, 124188.

Berle, A. \& Means, G. (1932). The modern corporation and private property. Harcourt, Brace \& World Inc, New York. 


\section{https://doi.org/10.2307/3475545}

Berman, S. L., Wicks, A. C., Kotha, S. \& Jones, T. M. (1999). Does stakeholder orientation matter? The relationship between stakeholder management models and firm financial performance. Academy of Management journal, 42(5), 488-506. https://doi.org/10.2307/256972

Brixy, U. \& Grotz, R. (2007). Regional patterns and determinants of birth and survival of new firms in western Germany. Entrepreneurship \& Regional Development, 19 (4), 293-312. https://doi.org/10.1080/08985620701275510

Bunn, P. \& Redwood. V. (2003). Company accounts based modeling of business failures and the implications for financial stability bank of England. Discussion Paper, No. 201. https://doi.org/10.2139/ssrn.598276

Campbell, J.L. (2003). States, politics, and globalization: why institutions still matter. In The Nation-State in Question, Paul TV, Ikenberry GJ, Hall AJ (eds). Princeton University Press: Princeton, NJ; 234-259.

Carter, R., \& Van Auken, H. (2006). Small firm bankruptcy. Journal of Small Business Management, 44(4), 493512. https://doi.org/10.1111/j.1540-627x.2006.00187.x

Casasola, M.J. \& Cardone, C. (2009). Too important to fail: ¿Favorecen las relaciones bancarias la situación crediticia de las PYMES españolas? Universia Business Review, 24, 12-29.

Cegarra-Leiva, D., Sánchez-Vidal, M. E., \& CegarraNavarro, J. G. (2012). Work life balance and the retention of managers in Spanish SMEs. The International Journal of Human Resource Management, 23(1), 91-108. https://doi. org/10.1080/09585192.2011.610955

Choi, Y. \& Lin, Y. (2009). Consumer response to crisis: exploring the concept of involvement in matte product recalls. Public Relations Review, 35, 18-22. https://doi.org/ 10.1016/j.pubrev.2008.09.009

Choi, J. \& Wang, H. (2009). Stakeholder relations and the persistence of corporate financial performance. Strategic Management Journal, 30(8), 895-907. https://doi.org/10. 1002/smj.759

Clarkson, M. E. (1995). A stakeholder framework for analysing and evaluating corporate social performance. Academy of Management Review, 20(1), 92- 117. https: //doi.org/10.5465/amr.1995.9503271994

Correa, A., Acosta, M. \& González, A.L. (2003). La insolvencia empresarial: Un análisis empírico para la pequeña y mediana empresa. Revista de Contabilidad-Spanish Accounting Review, 12, 47-79.

Derry, R. (2012). Reclaiming marginalized stakeholders. Journal of Business Ethics, 111(2), 253-264. https://doi. org/10.1007/s10551-012-1205-X

Donaldson, T. \& Preston, L. E. (1995). The stakeholder theory of the corporation: Concepts, evidence, and implications. Academy of Management Review, 20(1), 65-91. https: //doi.org/10.3138/9781442673496-011

Donker, H., Poff, D. \& Zahir, S. (2008). Corporate values, codes of ethics, and firm performance: A look at the Canadian context. Journal of Business Ethics, 82(3), 527-537. https://doi.org/10.1007/s10551-007-9579-x

Dowell, G., Shackell, M. \& Stuart, N. (2011). Boards, CEOs, and surviving a financial crisis: Evidence from the internet shakeout. Strategic Management Journal, 32(10), 1025-1045. https://doi.org/10.1002/smj.923

Dunham, L., Freeman, R.E., \& Liedtka, J. (2006). Enhancing stakeholder practice: A particularized exploration of community. Business Ethic Quarterly, 16(1), 23-42. https: //doi.org/10.5840/beq20061611
European Commission.

2003/361/EC.

Everett, J. \& Watson, J. (1998) Small Business Failure and External Risk Factors. Small Business Economics, 11, 371390.

Fassin, Y. (2012). Stakeholders management, reciprocity and stakeholder responsibility. Journal of Business Ethics, 109(1), 83-96. https://doi.org/10.1007/ s10551-012-1381-8

Fassin, Y., de Colle, S., \& Freeman, R. E. (2017). Intrastakeholder alliances in plantclosing decisions: A stakeholder theory approach. Business Ethics: A European Review, 26(2), 97-111. https://doi.org/10.1111/beer.12136

Fisher, K., Geenen, J., Jurcevic, M., McClintock, K. \& Davis, G. (2009). Applying assetbased community development as a strategy for CSR: a Canadian perspective on a win-win for stakeholders and SMEs. Business Ethics: A European Review, 18(1), 66-82. https://doi.org/10.1111/j.1467-8608. 2009.01549.x

Freeman, E. (1984). Strategic management: A stakeholder approach. Boston, Pitman.

Freeman, R.E., Harrison, J.S., Parmar, B.L. \& Colle, S.D. (2010). Stakeholder theory. The state of the art. Cambridge University Press, Cambridge.

Freund, Y. \& Schapire, R. E. (1996). Experiments with a new boosting algorithm. In Icml, 96, 148-156.

Friedman, A. L., \& Miles, S. (2006). Stakeholders: Theory and practice. Oxford University Press on Demand.

Frooman, J. (1999). Stakeholder influence strategies. Academy of Management Review, 24, 2, 191-205. https: //doi.org/10.5465/amr.1999.1893928

García, D., Arqués, A., \& Calvo-Flores, A. (1995). Un modelo discriminante para evaluar el riesgo bancario de los créditos a empresas. Revista Española de Financiación y Contabilidad, 82, 175-200.

Gilbert, L. R., Menon, K., \& Schwartz, K. B. (1990). Predicting bankruptcy for firms in financial distress. Journal of Business Finance \& Accounting, 17(1), 161-171. https: //doi.org/10.1111/j.1468-5957.1990.tb00555.x

Goktan, M. S., Kieschnick, R. \& Moussawi, R. (2018). Corporate governance and firm survival. Financial Review, 53(2), 209-253. https://doi.org/10.1111/fire.12161

Goxens, M.A. \& Gay, J.M. (2005). Análisis de estados contables: Diagnóstico económico-financiero. Pearson Educación, Madrid, 369

Granda, G. \& Trujillo, R. (2011). La gestión de los grupos de interés (Stakeholders) en la estrategia de las organizaciones. Economía industrial, 1(381), 71-76.

Grant R. (1996). Toward a knowledge-based theory of the firm. Strategic Management Journal, Winter Special, 17, 109-122. https://doi.org/10.1002/smj.4250171110

Griffin, J. J. (2017). Tracing stakeholder terminology then and now: Convergence and new pathways. Business Ethics: A European Review, 26(4), 326-346. https://doi.org/ 10.1111/beer.12158

Hambrick, D.C., \& D’Aveni, R.A. (1988). Large corporate failures as downward spirals. Administrative Science Quarterly, 33, 1-23. https://doi.org/10.2307/2392853

Harrison, J.S., Bosse, D.A. \& Phillips, R.A. (2010). Managing for stakeholders, stakeholder utility functions, and competitive advantage. Strategic Management Journal, 31(1), 58-74. https://doi.org/10.1002/smj.801

Harrison, J. S. \& Freeman, R. E. (1999). Stakeholders, social responsibility, and performance: Empirical evidence and theoretical perspectives. Academy of Management Journal, 42(5), 479-485. https://doi.org/10.5465/256971

Herrera, J., Larrán, M., Lechuga, P. \& Martínez, D. (2016). 
Corporate social responsibility practices in Spanish small and medium business: Explanatory factors analysis. Revista de Contabilidad-Spanish Accounting Review, 19(1), 31-44.

Hessels, J., \& Terjesen, S. (2010). Resource dependency and institutional theory perspectives on direct and indirect export choices. Small business economics, 34(2), 203-220. https://doi.org/10.1007/s11187-008-9156-4

Hillman, A. J. \& Keim, G. D. (2001). Shareholder value, stakeholder management, and social issues: What's the bottom line? Strategic Management Journal, 125139. https://doi.org/10.1002/1097-0266(200101)22:2/ /<125::aid-smj150>3.0.co;2-h

Hummels, H. (1998). Organizing ethics: A stakeholder debate. Journal of Business Ethics, 17(13), 1403-1419.

International Monetary Fund. (2012). World economic outlook. Growth resuming. Dangers Remain, Washington.

James, S.D. (2016). Strategic bankruptcy: A stakeholder management perspective. Journal of Business Research, 69, 492-499. https://doi.org/10.1016/j.jbusres.2015.05.006

Jawahar, I.M. \& McLaughlin, G.L. (2001). Toward a Descriptive Stakeholder Theory: An Organizational Life Cycle Approach. Academy of Management Review, 26 (3), 397414. https://doi.org/10.2307/259184

Jensen, M.C. (1983). Organization theory and methodology. Accounting Review, 50, 319-39. https://doi.org/10. 2139/ssrn.94036

Jensen, M.C. \& Meckling, W. H. (1976). Theory of the firm, managerial behaviour, agency costs and ownership structure. Journal Financial Economic, 3, 305-360. https://doi.org/10. 1016/0304-405x(76)90026-x

John, T. A. (1993). Accounting measures of corporate liquidity, leverage, and costs of financial distress. Financial Management, 22(3), 91-100. https://doi.org/10.2307/ 3665930

Jones, F. L. (1987). Current techniques in bankruptcy prediction. Journal of Accounting Literature, 6, 131-164.

Jones, T. M. \& Wicks, A. C. (1999). Convergent stakeholder theory. Academy of Management Review, 24(2), 206221. https://doi.org/10.5465/amr.1999.1893929

Kacperczyk, A. (2009). With greater power comes greater responsibility? Takeover protection and corporate attention to stakeholders. Strategic Management Journal, 30(3), 261285. https://doi.org/10.1002/smj.733

Kane, G. D., Richardson, F. M. \& Graybeal, P. (1996). Recessioninduced stress and the prediction of corporate failure. Contemporary Accounting Research, 13(2), 631-650. https://doi.org/10.1111/j.1911-3846.1996.tb00517.x

Kassinis, G., \& Vafeas, N. (2006). Stakeholder pressures and environmental performance. Academy of Management Journal, 49(1), 145-159. https://doi.org/10.5465/ amj.2006.20785799

Keasey, K. \& Watson, R. (1987). Nonfinancial symptoms and the prediction of small company failure, a test of Argentis hypotheses. Journal of Business Finance \& Accounting, 14(3), 335-354. https://doi.org/10.1111/j.1468-5957. 1987.tb00099.x

Keasey, K. \& Watson, R. (1991). Financial distress prediction models: a review of their usefulness. British Journal of Management, 2(2), 89-102. https://doi.org/10.1111/j. 1467-8551.1991.tb00019.x

Koh, H. C., \& Killough, L. N. (1990). The use of multiple discriminant analysis in the assessment of the goingconcern status of an audit client. Journal of Business Finance \& Accounting, 17(2), 179-192. https://doi.org/10.1111/j. 1468-5957.1990.tb00556.x

Labatut, G. L., Campillo, P. \& Ferrer, E. (2009). Model- ización temporal de los ratios contables en la detección del fracaso empresarial de la PYME española. Spanish Journal of Finance and Accounting/Revista Española de Financiación y Contabilidad, 38(143), 423-447. https://doi.org/10.1080/ 02102412.2009 .10779672

Laffarga, J., Martín, J., \& Vázquez, J. (1985). La predicción de la crisis bancaria: El caso español. Revista Española de Financiación y Contabilidad, 20, 66, 151-163.

Larrinaga-González, C. (2007). Sustainability reporting, insights from neo-institutional theory. In J. Unerman, B. O'Dwyer and J. Bebbington (eds). Sustainability accounting and accountability. London, Routledge. https://doi.org/10. 4324/noe0415384889.ch8

Law 22/2003, Spanish Insolvency Act 22-2003, BOE (Officil State Bulletin), 164, 10 July.

Lee, D.Y. \& Tsang, E.W.K. (2001). The effects of entrepreneurial personality, background and network activities on venture growth. Journal of Management Studies, 38 (4): 583602. https://doi.org/10.1111/1467-6486.00250

Lemmon, M. L. \& Lins, K. V. (2003). Ownership structure, corporate governance, and firm value, evidence from the east Asian financial crisis. The Journal of Finance, 58(4), 14451468. https://doi.org/10.1111/1540-6261.00573

Lizárraga, F. (1997). Utilidad de la información contable en el proceso de fracaso, análisis del sector industrial de la mediana empresa española. Revista Española de Financiación y Contabilidad, 93, 871-915.

Madrid-Guijarro, A., García-Pérez-de-Lema, D., \& Van Auken, H. (2011). An analysis of non-financial factors associated with financial distress. Entrepreneurship and Regional Development, 23(3-4), 159-186. https://doi.org/10.1080/ 08985620903233911

Manzaneque, M., García-Pérez-De-Lema, D. \& Antón, M. (2015). Bootstrap Replacement to Validate the Influence of the Economic Cycle on the Structure and the Accuracy Level of Business Failure Prediction Models. Journal of Forecasting, 34(4), 275-289. https://doi.org/10.1002/for.2327

Manzaneque, M., Priego, A. M., \& Merino, E. (2016). Corporate governance effect on financial distress likelihood: Evidence from Spain. Revista de Contabilidad-Spanish Accounting Review, 19(1), 111-121. https://doi.org/10.1016/ j.rcsar.2015.04.001

McDonald, L. \& Härtel, C.E.J. (2000). Applying the involvement construct to organizational crisis. Proceedings of the Australian and New Zealand Marketing Conference, Gold Coast, Australia.

McDonald, L., Sparks, B. \& Glendon, A. I. (2010). Stakeholders reactions to company crisis communication and causes. Public Relations Review, 36, 263-271. https://doi. org/10.1016/j.pubrev.2010.04.004

Mellahi, K. \& Wilkinson, A. (2004). Organizational failure, a critique of recent research and a proposed integrative framework. International Journal of Management Reviews, 5(1), 21-41. https://doi.org/10.1111/j.1460-8545. 2004.00095.X

Mensah, Y. M. (1984). An examination of the stationarity of multivariate bankruptcy prediction models, a methodological study. Journal of Accounting Research, 380-395. https://doi.org/10.2307/2490719

Minoja, M. (2012). Stakeholder management theory, firm strategy, and ambidexterity. Journal of Business Ethics, 1-16. https://doi.org/10.1007/s10551-012-1380-9

Mitchell, R. K., Agle, B. R., \& Wood, D. J. (1997). Toward a theory of stakeholder identification and salience: Defining the principle of who and what really counts. Academy of Management Review, 22(4), 853-886. https://doi.org/10. 


\section{$2307 / 259247$}

Moore, S. B. \& Manring, S. L. (2009). Strategy development in small and medium sized enterprises for sustainability and increased value creation. Journal of Cleaner Production, 17(2), 276-282. https://doi.org/10.1016/j.jclepro.2008.06. 004

Mora, A. (1994). Los modelos del fracaso empresarial, una aplicación empírica del logit. Revista Española de Financiación y Contabilidad, 24(78), 203-233.

Neville, B. A. \& Menguc, B. (2006). Stakeholder multiplicity, toward an understanding of the interactions between stakeholders. Journal of Business Ethics, 66(4), 377-391. https://doi.org/10.1007/s10551-006-0015-4

Ohlson, J. A. (1980). Financial ratios and the probabilistic prediction of bankruptcy. Journal of accounting research, 109-131. https://doi.org/10.2307/2490395

Padilla, J., \& Requejo, A. (2000). The Cost and Benefits of the Strict Protection of Creditor Rights: Theory and Evidence. https://doi.org/10.2139/ssrn.1814659

Pajunen, K. (2006). Stakeholders influences in organizational survival. Journal of Management Studies, 43(6), 12611288. https://doi.org/10.1111/j.1467-6486.2006.00624.x

Parmar, B. L., Freeman, R. E., Harrison, J. S., Wicks, A. C., Purnell, L. \& De Colle, S. (2010). Stakeholder theory, the state of the art. Academy of Management Annuals, 4(1), 403445. https://doi.org/10.1080/19416520.2010.495581

Penrose, E. (1995). The Theory of the Growth of the Firm. Oxford UK: Basil Blackwell, 2nd Edition. https://doi.org/10. 1093/0198289774.001.0001

Pérez-Carballo, J.F. (2001). Del valor de la empresa a la creación de valor. Estrategias para empresarios y financieros. Biblioteca Civitas, Economía y Empresa, Madrid.

Perrini, F. (2006). SMEs and CSR theory, evidence and implications from an Italian perspective. Journal of Business Ethics, 67(3), 305-316. https://doi.org/10.1007/ s10551-006-9186-2

Peursem, K. \& Chan, Y. C. (2014). Forecasting New Zealand corporate failures 2001-10, opportunity lost? Australian Accounting Review, 24(3), 276-288. https://doi.org/ 10.1111/auar.12029

Pfeffer, J. \& Salancik, G. R. (1978). The external control of organizations. Harper \& Row, New York. https://doi.org/ $10.2307 / 2392573$

Pinnuck, M. (2012). A review of the role of financial reporting in the global financial crisis. Australian Accounting Review, 22(1), 1-14. https://doi.org/10.1111/j.1835-2561. 2011.00155.x

Platt, H. D., Mirick, C. R., \& Platt, M. B. (2011). Ethics, bankruptcy and greed: the unintended consequences for landlords of the 2005 bankruptcy amendments. International Journal of Business Governance and Ethics, 6(3), 249263. https://doi.org/10.1504/ijbge.2011.043240

Platt, H. D., \& Platt, M. B. (1990). Development of a class of stable predictive variables: the case of bankruptcy prediction. Journal of Business Finance \& Accounting, 17(1), 3151. https://doi.org/10.1111/j.1468-5957.1990.tb00548.x

Post J.E., Preston L.E. \& Sachs, S. (2002). Managing the extended enterprise, the new stakeholder view. California Management Review, 45(1), 6-28. https://doi.org/10.2307/ 41166151

Preston, L.E. \& Sapienza, H. (1990). Stakeholder management and corporate performance. Journal of Behavioral Economics, 19, 361-375. https://doi.org/10.1016/ 0090-5720(90)90023-Z

Priego, A., Banegas, R. \& Manzaneque, M. (2012). Stakeholders y riesgo empresarial desde la perspectiva de la in- formación contable. Strategy \& Management Business Review, $33-57$.

Priego, A., Manzaneque, M. \& Merino, E. (2014). Business failure: Incidence of stakeholders' behavior. Academia Revista Latinoamericana de Administración, 27(1), 75-91. https://doi.org/10.1108/arla-12-2013-0188

Russo, A. \& Tencati, A. (2009). Formal vs. informal CSR strategies, evidence from Italian micro, small, medium-sized, and large firms. Journal of Business Ethics, 85, 339-353. https://doi.org/10.1007/s10551-008-9736-x

San-José, L. \& Cowton, C.J. (2009). El crédito comercial y la crisis crediticia, un análisis descriptivo en Europa, Reino Unido y España. In F.J. Cossío-Silva (eds), in administrando en entornos inciertos (Managing in Uncertain Environment). Escuela Superior de Gestión Comercial y Marketing, Sevilla, 23-55.

Schutjens, V. A., \& Wever, E. (2000). Determinants of new firm success. Papers in Regional Science, 79(2), 135-153. https://doi.org/10.1007/s101100050040

Sen, S., \& Cowley, J. (2013). The relevance of stakeholder theory and social capital theory in the context of CSR in SMEs: An Australian perspective. Journal of Business Ethics, 118(2), 413-427. https://doi.org/10.1007/ s10551-012-1598-6

Somoza, A. (2001). La Consideración de Factores Cualitativos, Macroeconómicos y Sectoriales en los Modelos de Predicción de la Insolvencia Empresarial. Su Aplicación al Sector Textil y Confección de Barcelona (1994-1997). Papeles de Economía Española, 89, 90, 402-416

Tabachnick, B. G. \& Fidell, L. S. (1996). Analysis of covariance. Using Multivariate Statistics, 8(1), 321-374.

Tantalo, C. \& Priem, R. L. (2016). Value creation through stakeholder synergy. Strategic Management Journal, 37(2), 314-329. https://doi.org/10.1002/smj.2337

Tascón, M.T., \& Castaño, F.J. (2012). Variables y modelos para la identificación y predicción del fracaso empresarial: revisión de la investigación empírica reciente. Revista de Contabilidad-Spanish Accounting Review, 15(1), 7-58. https://doi.org/10.1016/s1138-4891(12)70037-7

Van Hemmen, S. (2000). Reasignación de recursos y resolución de contratos en el sistema concursal español. Paper presented at the annual meeting of the $\mathrm{X}$ Congreso Nacional de ACEDE.

Villanueva-Villar, M., Rivo-Lopez, E. \& Lago-Penas, S (2016). On the relationship between corporate governance and value creation in an economic crisis, empirical evidence for the Spanish case. BRQ Business Research Quarterly, 19(4), 233-245. https://doi.org/10.1016/j.brq.2016.06. 002

Von Stein, J. H., \& Ziegler, W. (1984). The prognosis and surveillance of risks from commercial credit borrowers. Journal of Banking and Finance, 8, 249-268. https://doi. org/10.1016/0378-4266(84)90006-2

Wood, R. (1947) Or forfeit freedom. New York, Doubleday. Worthington, I., Ram, M. \& Jones, T. (2006). Exploring corporate social responsibility in the UK Asian small business community. Journal of Business Ethics, 67(2), 201-217. https://doi.org/10.1007/s10551-006-9024-6

Zavgren, C. V., \& Friedman, G. E. (1988). Are bankruptcy prediction models worthwhile? An application. Management International Review, 28(1), 34. 